J. Akademika Kim. 5(1): 1-7, February 2016

ISSN 2302-6030 (p), 2477-5185 (e)

\title{
PENGARUH LAMA PENYIMPANAN RIMPANG KUNYIT (Curcuma domestica Vabl) TERHADAP DAYA HAMBAT ANTIOKSIDAN
}

\section{Effect of Storage Time of Tumeric (Curcuma domestica Vahl) On Inhibition Of Antioxidant}

\author{
*Armin H. Suparmajid, Sri Mulyani Sabang, dan Ratman \\ Pendidikan Kimia/FKIP - Universitas Tadulako, Palu - Indonesia 94118 \\ Received 01 December 2015, Revised 01 January 2016, Accepted 02 February 2016
}

\begin{abstract}
The research about the effect of storage time of tumeric (Curcuma domestica Vabl) for inhibition of antioxidant has been conducted. The study aims to determine the effect of storage time of tumeric (Curcuma domestica Vahl) for inhibition of antioxidants as well as to determine how much inhibition of antioxidant found in tumeric. This study uses a variation of storage time namely 8,13 and 18 days. The extract of tumeric is obtained by maceration method using ethanol. The antioxidant activity of turmeric is measured by UV Vis spectrophotometry in which DPPH (1,1-difenil-2-pikrilhidrazil) as a reagent. The absorbance measurements is carried out at a wavelength of $517 \mathrm{~nm}$ to determine the percentage of inhibition of antioxidant in turmeric and vitamin $C$ (as a positive control). The results reveal that percentage of inhibition of vitamin $C$ is $56.68 \%$, while the percentage of inhibition of turmeric decrease during storage. Based on the data obtained, turmeric with storage time of 8 days is $43.96 \%$, turmeric with storage time of 13 days is $23.27 \%$, and turmeric with storage time of 18 days is $11.92 \%$. This study shows that the effect of storage time on the inhibition of antioxidant turmeric are characterized by a decrease of percentage inhibition of antioxidants in turmeric during the storage period.
\end{abstract}

Keywords: Inhibition of antioxidant, extract of turmeric, 1,1-diphenyl-2-picrylhydrazyl (DPPH).

\section{Pendahuluan}

Perubahan pola hidup masyarakat berdampak pada munculnya berbagai penyakit degeneratif. Salah satu penyebab meningkatnya penderita penyakit degeneratif di masyarakat adalah kerusakan sel tubuh sebagai akibat aktivitas unsur radikal bebas yang terdapat dalam bahan makanan. Untuk meningkatkan daya tahan tubuh dibutuhkan asupan makanan, baik berupa sayuran, buahbuahan yang merupakn sumber antioksidan. Aktivitas antioksidan dapat menangkap radikal bebas, sehingga sel-sel yang rusak dapat dicegah ataupun diperbaiki. Selain dari sayuran dan buah sumber antioksidan juga dapat berasal dari tanaman-tanaman obat, jahe, mengkudu, lidah buaya, pegagan, temulawak, kunyit dan lainlain. Senyawa-senyawa kimia yang terkandung dalam tanaman tersebut dapat bermanfaat

*Correspondence:

Armin H. Suparmajid

Program Studi Pendidikan Kimia, Fakultas Keguruan dan

IImu Pendidikan, Universitas Tadulako

email: armin.h.suparmajid@gmail.com

Published by Universitas Tadulako 2016

sebagai sumber antioksidan misalnya flavonoid, tanin, polifenol dan lain-lain. Demikian juga diketahui senyawa bioaktif rimpang kunyit yaitu asam askorbat, beta karoten, asam kafeik, kurkumin, eugenol, p-asam kumarik(Suhaj, 2006).

Salah satu tanaman yang banyak digunakan sebagai obat tradisional adalah tanaman kunyit (Curcuma domestica Vahl). Zat yang berpengaruh penting dalam kunyit adalah kurkumin dan minyak atsiri, vitamin C, vitamin E dan Selenium, dimana peran antara satu dengan yang lainnya saling mendukung yaitu sebagai antioksidan alami (Muchtadi \& Sugiono, 1992). Warna kuning pada kunyit disebabkan oleh adanya 3 pigmen utama yaitu kurkumin 1,7-bis-(4-hidroksi-3-metoksi fenil)- 1,6-heptadiena- 3,5-dione, dimetoksikurkumin dan bis dimetoksi-kurkumin. Senyawa kurkumin ini diketahui mempunyai aktivitas antioksidan yang tinggi (Sharma, dkk., 2005).

Antioksidan yang terkandung dalam kunyit mempunyai peran penting dalam menghambat 
terjadinya ketengikan oksidatif dalam ransom, untuk mencegah asam lemak tak jenuh dan vitamin-vitamin yang terlarut dalam lemak dari pengrusakan-pengrusakan yang disebabkan oleh peroksida lipida. Peroksida berpotensi untuk memproduksi ion radikal bebas yang dapat merusak membran sel, karena komponen terpenting membran sel mengandung asam lemak tak jenuh ganda yang sangat rentan terhadap serangan radikal bebas (Salim, 1999).

Radikal bebas atau senyawa oksigen reaktif didefinisikan sebagai suatu atom atau molekul atau senyawa yang mengandung satu atau lebih elektron yang tidak berpasangan. Contohnya, superoksida $\left(\mathrm{O}^{2-}\right)$, hidroksil $\left(\mathrm{OH}^{-}\right)$, dan nitrioksida $\left(\mathrm{NO}^{-}\right)$. Karena elektron radikal bebas tidak berpasangan, sifat ini mempunyai kecenderungan untuk bereaksi dengan molekul sel dengan menarik elektron dari molekul tersebut, sehingga terbentuk radikal bebas baru yang lebih reaktif dan dapat menyebabkan kerusakan atau kematian sel. Derajat kekuatan setiap radikal bebas berbeda, senyawa yang paling berbahaya adalah hidroksil $\left(\mathrm{OH}^{-}\right)$karena memiliki reaktivitas tinggi (Salim, 1999).

Antioksidan merupakan senyawa yang dapat menghambat reaksi oksidasi, dengan mengikat radikal bebas dan molekul yang sangat reaktif sehingga kerusakan sel akan dihambat. Antioksidan terdapat dalam beberapa bentuk, diantaranya vitamin, mineral, dan fitokimia. Berbagai tipe antioksidan bekerjasama melindungi sel normal dan menetralisir radikal bebas (Andayani, dkk., 2008).

Diketahui bersama, kunyit yang digunakan sebagai obat dan bumbu masak kebanyakan di peroleh dari pasaran. Kunyit yang berasal dari pasaran mempunyai masa simpan yang relatif lama dari masa panennya. Masa simpan kunyit tentunya berpengaruh terhadap kandungan senyawa yang bersifat sebagai antioksidan didalamnya seperti senyawa kurkuminoid protein, fosforus, kalium, besi dan vitamin C. Vitamin $\mathrm{C}$ merupakan vitamin yang tidak stabil dari semua vitamin dan mudah rusak selama masa penyimpanan. Faktor-faktor yang dapat mempengaruhi kerusakan antioksidan selama masa penyimpanansetelah masa panen antara lain karena terjadinya proses metabolik setelah rimpang kunyit tersebut dipisahkan dari pohonnya, proses respirasi dan transpirasi yang berlangsung terus menerus terutama pada permukaan rimpang kunyit, menyebabkan perombakan substrat organik. Proses respirasi meliputi pengambilan $\mathrm{O}_{2}$ dan pengeluaran
$\mathrm{CO}_{2}$, sedangkan proses transpirasi meliputi penguapan $\mathrm{H}_{2} \mathrm{O}$ (Puspitasari, 2009).

Tulisan ini bertujuan untuk mengetahui bagaimana pengaruh lama penyimpanan rimpang kunyit (Curcuma domestica Vabl) terhadap daya hambat antioksidan serta untuk mengetahui seberapa besar daya hambat antioksidan yang terdapat pada rimpang kunyit tersebut.

\section{Metode \\ Alat dan Bahan}

Peralatan yang digunakan meliputi: alat-alat gelas (gelas kimia, gelas ukur, pipet tetes, labu ukur, Erlenmeyer), neraca analitik, spatula, magnetic stirer, aluminium foil, blender, corong, kertas saring, spektrofotometer UVVis PG Instrumen Ltd. Sedangan bahan yang digunakan meliputi rimpang kunyit, Vitamin C (Merck), Etanol (Merck), dan pereaksi DPPH (Merck).

\section{Prosedur Penelitian}

Tahapan - tahapan pada penelitian ini dikutip dari Septianingsih (2013) yang di modifikasi sedemikian rupa.

\section{Tahap I}

\section{Preparasi Sampel}

Rimpang kunyit dibersihkan dari tanah yang menempel kemudian dicuci dengan air bersih, setelah itu, sampel didiamkan dengan variasi waktu selama 8, 13dan 18 hari ditempat yang terlindung cahaya. Sampel yang telah didiamkan kemudian dipotong-potong kecil,dan dikeringkan dengan cara dianginanginkan.Setelah itu rimpang kunyit yang telah kering dihaluskan dengan menggunakan blender. Serbuk kunyit yang telah halus siap untuk diekstraksi.

\section{Tahap II \\ Pembuatan Ekstrak}

5 gram serbuk rimpang kunyit ditimbang kemudian sampel dimasukkan ke dalam erlenmenyer dan ditambahkan dengan 50 $\mathrm{mL}$ etanol $96 \%$. Erlenmeyer yang telah berisi sampel ditutup dengan aluminium foil dan direndam selama 3 x 24 jam (72 jam) sambil dikocok menggunakan shaker. Setelah 72 jam ekstrak disaring menggunakan kertas saring dan filtrat yang diperoleh digunakan dalam pengujian antioksidan.

\section{Tahap III \\ Uji Daya Hambat Antioksidan}

9,8 mg DPPH ditimbang kemudian serbuk DPPH ditambahkan dengan pelarut etanol 
96\% kedalam labu ukur $50 \mathrm{~mL}$, volume campurandicukupkan hinggatanda garis pada labu ukur. Larutan DPPH 0,5 mM diambil sebanyak $5 \mathrm{~mL}$, kemudian dimasukkan kedalam labu ukur $50 \mathrm{~mL}$, volume campuran dicukupkan dengan mencampurkan etanol 96\% hinggatandagaris pada labu ukur. Untuk pengujian ekstrak rimpang kunyit, sebanyak 50 mg ekstrak rimpang kunyit dilarutkan dalam labu ukur $50 \mathrm{~mL}$ dengan pelarut etanol 96\% kemudian volumecampuran dicukupkan hinggatanda garis. Untuk pengujian ekstrak vitamin $\mathrm{C}$, sebanyak $50 \mathrm{mg}$ vitamin C dicukupkanvolume akhir dengan etanol 96\% hingga $50 \mathrm{~mL}$. Larutan induk (ekstrak rimpang kunyit) dan larutan pembanding (ekstrak vitamin C) yang telah dibuat diambil masing-masing $5 \mathrm{~mL}$, kemudian dimasukkan ke dalam masing-masing labu ukur $50 \mathrm{~mL}$, kemudianmasing-masing larutan induk dan larutan pembanding ditambahkan $5 \mathrm{~mL}$ larutan $\mathrm{DPPH}$ dan volume campuran dicukupkan hingga tanda garis pada labu ukur dengan etanol $96 \%$. Kemudian masing-masing campuran yang telah ditambahkan larutan DPPH tersebut dihomogenkan dan disimpan ditempat yang terlindung cahaya pada temperatur rendah selama 25 menit, selanjutnya absorbansi diukur dengan spektrofotometri UV-VIS pada panjang gelombang $517 \mathrm{~nm}$. Semua pengerjaan dilakukan pada ruang yang terhindar dari cahaya.

Besarnya Daya Hambat antioksidan dihitung dengan rumus (Zuhra, dkk., 2008):

$$
\text { Daya hambat antioksidan }=\frac{(\text { absorbansi blanko - absorbansi sampel) }}{\text { absorbansi blanko }} \times 100 \%
$$

\section{Hasil dan Pembahasan}

Pada penelitian ini mencakup uji daya hambat antioksidan pada rimpang kunyit. Uji daya hambat antioksidan pada rimpang kunyit telah dilakukan secara Spektrofotometri sinar tampak dengan menggunakan metode 1,1-difenil-2-pikrilhidrazil (DPPH), yang memberikan hasil yang berbeda antara perlakuan yang satu dengan perlakuan yang lainnya.
Tabel 1. Data hasil ekstraksi rimpang kunyit

\begin{tabular}{cccc}
\hline Jenis Sampel & $\begin{array}{c}\text { Massa sampel } \\
(\mathrm{g})\end{array}$ & $\begin{array}{c}\text { Volume Etanol } \\
(\mathrm{mL})\end{array}$ & Massa Ekstrak (g) \\
\hline $\begin{array}{c}\text { Rimpang } \\
\text { kunyit } \\
\text { Vitamin C }\end{array}$ & 5,00 & $50 \mathrm{~mL}$ & 0,05 \\
\hline
\end{tabular}

Tabel 2. Data hasil pengukuran absorbansi ekstrak rimpang kunyit dan pembanding Vitamin $\mathrm{C}$ yang telah ditambahkan dengan larutan $\mathrm{DPPH}$

\begin{tabular}{ccc}
\hline \multirow{2}{*}{ Lama Penyimpanan (Hari) } & \multicolumn{2}{c}{ Absorbansi (A) } \\
\cline { 2 - 3 } & Rimpang Kunyit & Vitamin C \\
\hline 8 & 0,490 & 0,379 \\
13 & 0,671 & \\
18 & 0,770 & \\
\hline
\end{tabular}

Absorbansi blanko (DPPH 0,5 mM) $=0,875$

Tabel 3. Data hasil uji daya hambat antioksidan dari ekstrak rimpang kunyit dan larutan pembanding vitamin $\mathrm{C}$

\begin{tabular}{cccc}
\hline Sampel & Absorbansi & \% Daya Hambat & $\begin{array}{c}\text { Rata-Rata \% Daya } \\
\text { Hambat }\end{array}$ \\
\hline Vitamin C & 0,379 & 56,68 & 56,68 \\
& 0,377 & 56,45 & \\
\hline $\begin{array}{c}\text { Rimpang Kunyit } \\
\left(\mathrm{t}_{8}\right)\end{array}$ & $0,4,491$ & 43,88 & \\
& 0,490 & 44,00 & 43,96 \\
\hline $\begin{array}{c}\text { Rimpang Kunyit } \\
\left(\mathrm{t}_{13}\right)\end{array}$ & 0,490 & 44,00 & \\
& 0,671 & 23,31 & 23,27 \\
& 0,671 & 23,31 & \\
\hline $\begin{array}{c}\text { Rimpang Kunyit } \\
\left(\mathrm{t}_{18}\right)\end{array}$ & 0,771 & 11,88 \\
\hline & 0,770 & 12,00 & 11,92 \\
\hline
\end{tabular}


Antioksidan merupakan suatu senyawa yang dapat memperlambat atau menghambat terjadinya proses oksidasi dengan cara menyumbangkan satu atom hidrogen atau satu elektron untuk berikatan dengan radikal bebas. Antioksidan alami yang banyak terdapat pada tanaman umumnya berupa senyawa polifenol.

Kunyit (Curcuma domestica Vahl) mempunyai potensi sebagai antioksidan alami. Tanaman ini mengandung antioksidan dari golongan flavonoid. Kandungan utama kunyit adalah minyak atsiri dan kurkuminoid (Rukmana \& Saputra, 1995). Kunyit mengandung minyak atsiri keton sesquiterpena yaitu tumeron dan artumeron. Senyawasenyawa yang terkandung dalam kunyit memiliki aktivitas biologis sebagai anti bakteri, antioksidan dan anti hepatotoksik (Rukmana \& Saputra, 1995).

Ekstraksi merupakan suatu proses selektif yang dilakukan untuk mengambil zat-zat yang terkandung dalam suatu campuran dengan menggunakan pelarut yang sesuai. Metode pemisahan ini bekerja berdasarkan prinsip kelarutan Like Dissolve Like, yaitu pelarut polar akan melarutkan zat polar, dan sebaliknya (Khopkar, 2003).

Metode ekstraksi yang digunakan dalam penelitian ini yaitu secara maserasi dengan menggunakan pelarut etanol. Pelarut yang digunakan adalah etanol karena etanol merupakan pelarut yang sesuai untuk melarutkan senyawa organik dengan polaritas medium dengan sifat mudah menguap. Selain itu, etanol adalah pelarut paling aman karenatidak beracun.

Maserasi merupakan metode yang paling mudah dilakukan dan menggunakan peralatan yang sederhana,prinsip maserasiadalah mengekstraksi komponen yang terkandung dan dilakukan dengan cara merendam serbuksimplisia dalam cairan pelarut yang sesuai pada temperatur kamar terlindung dari cahaya, cairanpelarut akan masuk ke dalam sel melewati dinding sel. Isi sel akan larut karena adanyaperbedaan konsentrasi antara larutan di dalam sel dengan di luar sel. Larutan yangkonsentrasinya tinggi akan terdesak keluar dan diganti oleh cairan pelarut dengan konsentrasi rendah (proses difusi). Peristiwa tersebut berulang sampai terjadi keseimbangan konsentrasi antara larutan di luar sel dan di dalam sel. Endapan yang diperoleh dipisahkan dan filtratnya dipekatkan.

Tahap awal yang dilakukan pada penelitian ini yaitu menyiapkan sampel rimpang kunyit kemudian mengeluarkan sisa-sisa tanah yang menempel pada rimpang kunyit, setelah itu rimpang kunyit di simpan pada suhu ruangan dengan variasi waktu 8 hari, 13 hari dan 18 hari. Tujuan dari penyimpanan pada suhu ruang agar senyawa metabolit sekunder yang terkandung di dalamnya tidak rusak. Kemudian rimpang kunyit di kupas kulitnya kemudian dipotong kecil-kecil dan dikeringkan. Proses pengeringan juga dilakukan pada suhu ruang dan terlindung dari cahaya matahari. Pengeringan merupakan tahap pengolahan tanaman obat yang perlu mendapat perhatian karena akan berpengaruh terhadap mutu simplisia dan zat yang berkhasiat yang ada di dalamnya. Selanjutnya sampel rimpang kunyit yang sudah kering kemudian dihaluskan dengan menggunakan blender.

Tahap selanjutnya yaitu menimbang serbuk rimpang kunyit sebanyak 5 gram kemudian mengekstraksi dengan menggunakan pelarut etanol sebanyak $50 \mathrm{~mL}$. Proses ekstraksi dilakukan dengan proses maserasi selama 3 × 24 jam. Selanjutnya dilakukan proses penyaringan menggunakan kertas saring untuk memperoleh filtrat yang selanjutnya digunakan untuk menguji daya hambat atioksidan.

\section{Uji Aktivitas Antioksidan Rimpang Kunyit}

Pada penelitian ini uji daya hambat antioksidan pada ekstrak rimpang kunyit menggunakan metode pengujian DPPH. Metode uji antioksidan menggunakan DPPH adalah salah satu metode uji kuantitatif untuk mengetahui seberapa besar dayahambat rimpang kunyit sebagai antioksidan. Metode pengujian menggunakan DPPH merupakan metode yang konvensional dan telah lama digunakan untuk penetapan aktivitas senyawa antioksidan. Selain itu, pengerjaannya juga mudah, cepat dan sensitif untuk menguji aktivitas antioksidan dari ekstrak tanaman menggunakan DPPH secara spektrofotometer(Pourmorad, dkk., 2006).

Ekstrak etanol rimpang kunyit yang direaksikan dengan larutan DPPH, langsung mengubah warna ungu larutan DPPH menjadi kuning pucat. Pemeriksaan aktivitas antiradikal bebas DPPH secara spektrofotometri dilakukan dengan mereaksikan sampel dengan larutan DPPH pada panjang gelombang 517 $\mathrm{nm}$. Aktivitas radikal bebas diukur dengan menghitung jumlah pengurangan konsentrasi larutan DPPH. Peredaman tersebut dihasilkan oleh bereaksinya molekul DPPH dengan 
atom hidrogen yang dilepaskan satu molekul komponen sampel sehingga terbentuk senyawa 1,1- difenil-2-pikrilhidrazin (DPPH-H) dan menyebabkan terjadinya peluruhan warna DPPH dari ungu ke kuning (Zuhra, 2008). Aktivitas antioksidan penangkap radikal dapat diketahui melalui penurunan serapan tersebut(Oke \& Hamburger, 2002). Sebelum melakukan pengujian aktivitas antioksidan, terlebih dahulu mengukur absorban maksimum larutan DPPH 0,5 mM. MenurutHidayat (2005), serapan maksimum larutan DPPH ialah pada panjang gelombang $517 \mathrm{~nm}$. Berdasarkan data yang diperoleh, pada panjang gelombang $517 \mathrm{~nm}$, larutan DPPH 0,5 mM menunjukkan absorban yaitu 0,875 .

Sinar ultraviolet (UV) mempunyai panjang gelombang antara $200-400 \mathrm{~nm}$, dan sinar tampak (visible) mempunyai panjang gelombang 400-750 nm. Pengukuran spektrofotometri menggunakan alat spektrofotometer yang melibatkan energi elektronik yang cukup besar pada molekul yang dianalisis, sehingga spektrofotometer UV-Vis lebih banyak dipakai untuk analisis kuantitatif dibandingkan kualitatif. Spektrum UV-Vis sangat berguna untuk pengukuran secara kuantitatif. Konsentrasi dari analit di dalam larutan bisa ditentukan dengan mengukur absorban pada panjang gelombang tertentu dengan menggunakan hukum Lambert-Beer(Rohman \& Sugeng, 2007).Nilai absorbansi ekstrak rimpang kunyit berdasarkan lama penyimpanan dapat diilustrasikan pada kurva berikut.

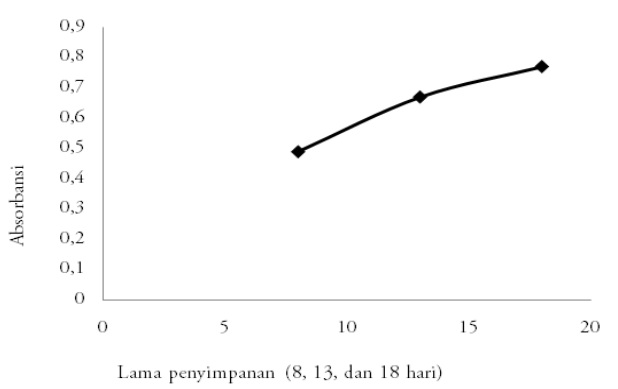

Grafik 1. Hubungan nilai absorbansi dan lama penyimpanan rimpang kunyit.

Berdasarkan Grafik 1. terlihat bahwa semakin lama masa penyimpanan rimpang kunyit maka semakin tinggi pula nilai absorban yang dihasilkan, yang artinya semakin rendah kemampuan peredaman radikal bebas DPPH. Hal tersebut dikarenakan, kemampuan antioksidan DPPH dalam menangkap radikal bebasnya menurun.

Adanya penurunan absorban menunjukkan peningkatan kemampuan peredaman radikal bebas DPPH (Hidayat, 2005). Reaksi DPPH dalam menangkap radikal bebas dapat dilihat pada Gambar berikut.
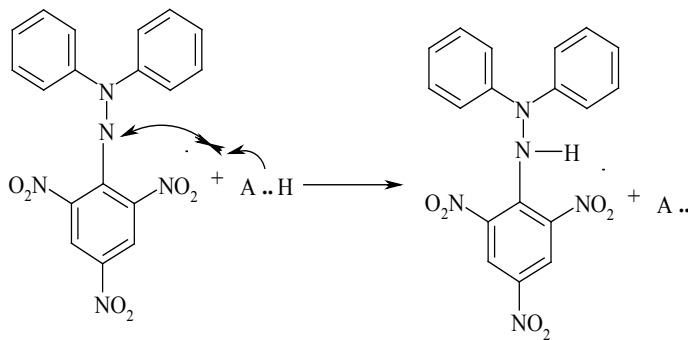

Gambar 1. Reaksi penangkapan radikal bebas oleh antioksidan(Molyneux, 2004).

Melalui reaksi tersebut, reaksi penangkapan radikal bebas oleh senyawa antioksidan melalui mekanisme donasi atom hidrogen sehingga akan dihasilkan DPPH-H (non radikal).

Pengujian daya hambat antioksidan dilakukan terhadap rimpang kunyit dengan perlakuan diulang sebanyak tiga kali dan serapannya diukur pada panjang gelombang optimum $517 \mathrm{~nm}$ karena pada panjang gelombang tersebut serapannya maksimum. Uji antioksidan dilakukan dengan tujuan untuk melihat efek penghambatan sampel terhadap proses oksidasi (Puspitasari, 2009). Daya antioksidan dapat dilihat pada kurva berikut.

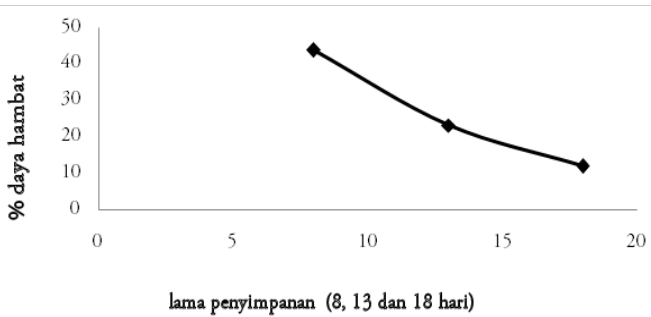

Garfik 2. Hubungan \% daya hambat antioksidan dan lama penyimpanan rinpang kunyit.

Berdasarkan hasil yang diperoleh yaitu diketahui pada masa simpan 8 hari, nilai absorbansi dari ekstrak rimpang kunyit yaitu 0,490. Namun pada masa simpan selama 13 hari nilai absorban ekstrak rimpang kunyit mengalami kenaikan yaitu 0,671 . Hal ini berarti daya hambat antioksidan rimpang kunyit mengalami penurunan dari 43,96\% 
menjadi 23,27\%. Pada masa simpan 18 hari nilai absorban ekstrak rimpang kunyit masih mengalami kenaikan yaitu 0,770 , yang berarti daya hambat antioksidan rimpang kunyit terus mengalami penurunan yaitu $11,92 \%$.

Hal ini menunjukkan bahwa hubungan antara nilai absorbansi dengan persen daya hambat antioksidan berbanding terbalik. Semakin tinggi nilai absorban yang di hasilkan maka semakin rendah persen daya hambat antioksidan suatu sampel. Hasil persentase penghambatan radikal bebas ini mendukung hasil pengamatan warna larutan DPPH setelah ditambahkan ke dalam ekstrak rimpang kunyit. Warna DPPH yang berkurang lebih banyak memiliki persentase penangkapan radikal bebas, yang berarti bahwa cahaya lebih banyak diteruskan dan cahaya yang diserap lebih sedikit. Berdasarkan hasil pengamatan, kunyit yang disimpan selama 13 hari warna larutan DPPH masih agak keunguan dibandingkan warna ekstrak rimpang kunyit yang disimpan selama 8 hari. Begitupula pada penyimpanan selama 18 hari, warna larutan DPPH tetap berwarna ungu. Hal ini berarti kemampuan antioksidan dalam meredam radikal bebas semakin berkurang yang menyatakan bahwa daya hambat antioksidan juga berkurang.

Menurut Pantastico (1997), kandungan asam askorbat dipengaruhi perubahan secara kimiawi dan mekanik, dimana secara kimiawi berhubungan dengan suhu yang tinggi. Pada penumpukkan suhu tinggi dapat menyebabkan perubahan keasaman selama penyimpanan dan secara mekanik berhubungan dengan terjadinya memar dan luka sayatan pada rimpang kunyit.

Kerusakan bahan pangan telah dimulai sejak bahan pangan tersebutdipanen. Penyebabutama kerusakan bahan pangan adalah pertumbuhan dan aktivitas mikroorganisme,aktivitas enzim dalam bahan pangan,baik suhu tinggi maupun suhu rendah, udara khususnya oksigen,kadar air dan kekeringan,cahaya, dan serangga, parasit serta pengerat. Selain itu pengaruh suhu selama penyimpanan berpengaruh terhadap aktivitas antioksidan karena setelah dipanen rimpang kunyit ditumpuk sehingga dapat menyebabkan perubahan keasaman, dan yang paling penting adalah pengaruh dari kerusakan mekanik dan memar, karena jika demikian maka rimpang kunyit akan sangat mudah mengalami pembusukan dan jika dimasukkan dalam tumpukan rimpang kunyit lainnya maka proses pembusukan akan semakin cepat terjadi dan pada akhirnya akan mengurangi zat gizi yang terkandung terutama kadar vitamin C rimpang kunyit tersebut yang berperan sebagai antioksidan.

\section{Kesimpulan}

Lama penyimpanan rimpang kunyit berpengaruh terhadap daya hambat antioksidan dan rimpang kunyit yang disimpan selama 8, 13 dan 18 hari memiliki daya hambat antioksidan berturut-turut sebesar 43,96\%, 23,27\% dan $11,92 \%$.

\section{Ucapan Terima Kasih}

Ucapan terima kasih penulis berikan kepada laboran Laboratorium Kimia Lanjut FKIP Universitas Tadulako yang banyak membantu penulis dalam menyelesaikan penelitian ini.

\section{Referensi}

Andayani, R., Lisawati, Y., \& Maimunah. (2008). Penentuan aktivitas antioksidan, kadar fenolat total dan likopen pada buah tomat (Solanum lycopersicum 1.). Jurnal Sains dan Teknologi Farmasi, 13(1), 31-37.

Hidayat, M. A. (2005). Pengujian antiradikal bebas difenilpikril hidrazil (DPPH) ekstrak buah kenitu (chrysophyllum cainito L.) dari daerah Jember. Jurnal Ilmu Dasar, 6(2), 110-114.

Khopkar, S. M. (2003). Konsep dasar kimia analitik. Jakarta: UI-Press.

Molyneux, P. (2004). The use of the stable free radical diphenylpicrylhydrazyl (DPPH) for estimating antioxidant activity. Journal Science Technology, 26(2), 211-213.

Muchtadi, T. R., \& Sugiono. (1992). Ilmu pengetahuan bahan pangan. Direktorat Jenderal Tinggi Pusat Antar Universitas Pangan dan Gizi. Bogor: Institut Pertanian Bogor.

Oke, J. M., \& Hamburger, M. O. (2002). Screening of some Ningeria medicinal plants for activity using 2,2-diphebyl,- 
picryl-hidrdzil (DPPH) radical. African Journal Biomedical Research, 5(1), 77-79.

Pantastico, E. B. (1997). Fisiologi pasca panen, penanganan dan pemanfaatan buah-buahan dan sayur-sayuran tropika dan subtropika. Yogyakarta: Handling and Gajah Mada University Press.

Pourmorad, F., Hosseinimehr, S. J., \& Shahabimajd, N. (2006). Antioxidant activity, phenol and flavonoid contents of some selected Iranian medicinal plants. African Journal of Biotechnology, 5(11), 1142-1145.

Puspitasari, I. (2009). Daya antioksidan vitamin C buah tomat yang beredar di pasar manonda Palu berdasarkan lama penyimpanan. (Skripsi), UNTAD, Palu.

Rohman, A., \& Sugeng, R. (2007). Aktivitas antioksidan subfraksi-subfraksi hasil fraksinasi lanjut ekstrak etil asetat buah mengkudu (morinda citrifolia L), artocarpus. Agritech, 7(2), 99-105.

Rukmana, R., \& Saputra, S. (1995). Hama tanaman dan teknik pengendalian. Jakarta: Bumi Aksara.
Salim, S. (1999). Radikal bebas dan antioksidan alami tumbuh-tumbuhan. Jurnal Penelitian Andalas, 11(12), 52-60.

Septianingsih, S. F. (2013). Uji aktivitas antioksidan ekstrak bawang butan (eleutherine palmifolia merr). (Skripsi), UNTAD, Palu.

Sharma, R. A., Gescher, A. J., \& Steward, W. P. (2005). Curcumin: The story so far. European Journal of Cancer, 41(B), 19551968.

Suhaj, M. (2006). Spice antioxidant isolation and their antiradikal activity: A review. Journal of Food Composition and Analysis, 19(6-7), 531-537.

Zuhra, C. F., Taringan, J. B., \& Sihotang, H. (2008). Aktivitas antioksidan senyawa flavonoid dari daun katuk (Sauropus androgunus (L) Merr.). Jurnal Biologi Sumatera, 3(1), 7-10.

Yulaikah, M. (2013). Penerapan jigsaw untuk meningkatkan hasil belajar siswa sekolah dasar. Jurnal Dinas Pendidikan Kota Surabaya, 6(4), 1-8. 